\title{
The Post-Pandemic Effects of Distance Education on Business Students: A Review of Expert Reports
}

\author{
Hooman Estelami ${ }^{1, *} \&$ Alexa Bezzone ${ }^{1}$ \\ ${ }^{1}$ Gabelli School of Business, Fordham University, New York City, USA \\ *Correspondence: Gabelli School of Business, Fordham University, New York City, USA. E-mail: \\ estelami@fordham.edu
}

Received: September 1, 2021

Accepted: January 5, 2022 Online Published: February 10, 2022

doi:10.5430/wje.v12n1p34

URL: https://doi.org/10.5430/wje.v12n1p34

\begin{abstract}
The period following the outbreak of the COVID-19 pandemic presented monumental challenges to education systems around the world. In the United States, the unique effects experienced by business students due to the rapid adoption of distance teaching methods resulted in significant changes in the students' learning environments. Using expert reports published in the media, this article systematically reviews the pattern of student experience cited by experts, and identifies six disruptive effects. Furthermore, the disruptive nature of the changes is contrasted with earlier historical contexts in which distance business education had been deployed to overcome societal challenges. The article concludes with a discussion of expected changes resulting from the massive deployment of distance education methods among business schools in the post-pandemic era.
\end{abstract}

Keywords: distance education, learning outcomes, educational performance

\section{Introduction}

The COVID-19 pandemic has been one of the most disruptive environmental forces of modern times (Schwab and Malleret, 2020). Its human and societal impacts exceed many of the major historical events that have affected the world in recent decades (Valeeva, 2021). The scale of the societal impact of the pandemic is comparable to that of the two world wars, the Great Depression and the 1918 influenza pandemic (Welna, 2020). From an economic perspective, it has negatively impacted many industries, including hospitality, air travel, healthcare, and education. At the same time, the pandemic has created a context for growth in industries that facilitate social distancing. For example, the telecommunications and information technology fields have grown, as they have supported business continuity for many industries and sectors, including education (Dincher and Wagner, 2021; Rippe et al., 2021).

It can be argued that similar to prior economic and environmental disruptions, the pandemic will impact higher education worldwide in the years to come. The norms for acceptable modes of student learning and the means of teaching have rapidly changed in response to the social distancing demands associated with COVID-19. In the months immediately following the outbreak, colleges and universities across the United States and elsewhere quickly transitioned into online learning institutions, reducing and, in many cases eliminating student population density on their campuses (Carey, 2020). This transition quickly reshaped the environment in which learning takes place, as old ways of in-person instruction became less prevalent.

The impact has been especially unique in business education, due to the unique pedagogical demands of business education. As a field of study, business is a field that requires a great deal of interaction between teacher and student. Furthermore, business education requires the application of concepts in a highly focused manner to train students to effectively address business problems. In addition, interaction among students and individual growth and development of students, through teamwork, presentations, case studies, simulations and other learning modes, uniquely define successful instructional practices in business education (Whatley, 2012).

In this article, we will first examine how other environmental forces of the past solidified the unique value proposition of distance education methods for business schools. This examination is done, in light of the relatively unknown fact that the pandemic outbreak was only one of many environmentally induced challenges that modern 
society has had to face in the delivery of educational services. Therefore, it is important to recognize the broader historical milestones in which distance education has been deployed to help societies overcome challenges facing them. Having recognized this historical context, the article will then focus on the COVID-19 era and empirically explore the specific case of business students' views regarding the impact of COVID-19 on their educational experience in the time period immediately following the pandemic outbreak. Utilizing expert reports published in the press, a taxonomy of student experiences will be identified and profiled. The paper will conclude with a discussion of the long-term implications of the pandemic on distance business education.

\section{Distance Business Education as a Historically Disruptive Force for Advancement}

A widely held misperception about distance education is that it is a modern phenomenon. Many educators and the general public incorrectly presume that due to the heavy reliance on technology, distance education is only a modern mode of teaching. This misperception can dilute the public's general appreciation for the instrumental role that distance education has historically had in advancing learning for the past two centuries.

As early as the first half of the 19th century, distance education modes were in full use in Europe in the form of correspondence courses (Edelson and Pittman, 2008). The course offerings covered both technical/professional fields of study (such as mathematics and short-hand writing) and liberal studies (such as history and home economics). During the second half of the 19th century, the American population expanded westward, resulting in the establishment of settlements and towns in the mid-western portions of the country. This expansion made it necessary to innovate educational offerings in order to address the literacy needs of the expanding population. Unique to this need was the desire to address the geographic dispersion of the population in this region. Geographic dispersion and the low concentration of the population made it financially challenging to operate schools and universities since the enrollment revenues needed to meet the fixed costs of operating an educational institution would be difficult, and in many cases impossible, to meet in low-density areas.

In the United States, the potential that distance education methods hold was recognized decades after it had been recognized in Europe (Simonson, Smaldino, Albright and Zvacek, 2009). With the westward expansion of the country, educators in states such as Ohio, Indiana, Illinois and Iowa had to identify efficient means of addressing the educational needs of the geographically dispersed population. Considering the high fixed costs associated with the establishment of physical school buildings and permanently staffing them, the notion of face-to-face instruction was economically challenged. While this challenge may not have been as prevalent in densely populated areas such as major metropolitan centers, it was a fundamental barrier to offering educational services in less densely populated areas such as smaller towns, villages, and the farmlands.

Therefore, starting from the early 1900s, several mid-western universities began to experiment with distance education methods, similar to the correspondence teaching methods used in Europe. This allowed them to expand their offerings and increase public literacy levels in the region while providing specialized educational programs catered to the unique needs of the region's population. The use of correspondence courses eventually gave way to more advanced communication technologies. For example, radio broadcasting was used to broadcast course lectures across a wide region. This allowed educational institutions to add the modality of audio to the students' learning experience while expanding their geographic reach far beyond what would have been possible through traditional face-to-face teaching on their campuses.

Technologies emerging in the 1950s and 1960s were further enablers of distance education, both in business and non-business disciplines. The two most notable technologies were the introduction of the television and the computer. Television enabled distance educators to supplement the educational content provided to the students with visual elements. This helped increase the ability to replicate the visual experience that students have in face-to-face instruction and allowed the educator to provide instruction on complex topics that may benefit from the visual presentation of the content, such as mathematics, physics and chemistry. Similarly, in the field of business education, course content related to fundamental business skills such as communications, leadership and negations could be more effectively taught using television, compared to earlier modes of distance teaching utilizing radio or text-based correspondence instruction.

The effectiveness of television as a mode of distance education was further enhanced by the availability of closed-circuit TV. In contrast to broadcast television, closed-circuit TV made it possible for independent and specialized delivery of courses to small groups of students, while at the same time enabling two-way communications between students and instructors (Allen and Seaman, 2013). This represented a leapfrogging 
advancement in distance education, which despite the fact that its first use dates back nearly half of a century, relates to a simpler representation of how modern distance education using synchronous web-based classes is delivered today.

The commercialization of computers, which also began in the 1960s resulted in the massive growth of communication abilities of organizations. Educational institutions were bound to benefit from this. As computer technology became widely accessible through the public's use of microcomputers in the 1990s, the notion that each student could possess his/her computer (and thereby benefit from individualized connectivity with a remotely located professor) made customized distance education a reality. This was further supported by the demilitarization of the internet (which had initially been used as a military communications system), making the delivery of online course content possible. The widespread public access and use of the internet also made instantaneous interactions between instructor and student a reality.

In the year 2001, the unique benefits and applicability of distance education methods at a time of crisis and disaster were recognized due to the tragic events of September 11th. While the horrific events of that day affected the entire nation, a select number of universities directly affected by the dire circumstances affecting the area of the Twin Towers in Manhattan were uniquely influenced by this tragedy. In downtown Manhattan, which was one of the epicenters of the horrible events of that day, the World Trade Center twin towers collapsed. The entire area became uninhabitable for months due to rescue and recovery efforts and the toxic clouds of fumes and dust.

As a result, institutions of higher education in this area could no longer operate and had to rapidly deploy distance modes of teaching. For example, Pace University's business programs, with their facilities located in the vicinity, quickly adapted to the reality of no longer having physical facilities available for face-to-face instruction and rapidly deployed online teaching methods. This not only propelled their business course offerings into the online domain, but it also allowed for a systematic comparison of the effectiveness of online teaching versus traditional teaching methods. Some of the resulting research studies have since become seminal pieces in the assessment of online teaching methods in business education (Priluck, 2004).

\section{The Pandemic Outbreak and Deployment of Distance Methods for Business Education}

The outbreak of the COVID-19 pandemic resulted in the rapid deployment of distance education methods to cope with the newly emerging environment and the unique requirements for the use of distance instructional methods across disciplines (Dincher and Wagner, 2021). In a matter of weeks, nearly all instruction at primary, secondary and higher levels was moved to remote modes of teaching. The pandemic resulted in the rapid deployment of distance communication tools, such as web-based live instruction, so that students and teachers can connect live without being in a common physical space. The emerging virtual nature of the classroom became possible through remote learning tools such as Zoom, Google Hangouts and Adobe Connect, and similar video conferencing platforms (Sharma, 2021; Rippe et al., 2021). Furthermore, instructional approaches using means other than video or telecommunication platforms had to be heavily relied upon. Lack of technological access, limited infrastructure bandwidth and shortages in technological supplies required the use of asynchronous modes of instruction (Pitman et al., 2021). The result was the deployment of an array of instructional methods, all of which relied on physical distance between instructor and student.

Interestingly, the use of distance methods as a mode of teaching, which had to be relied upon during the pandemic outbreak, dates back nearly two centuries and is testimony to the persistence of distance teaching methods in addressing some of the most fundamental educational delivery challenges associated with the physical distance that may exist between student and instructor. Since the early part of this century, the massive expansion of bandwidth capacity on the internet has made it possible for instructional material to take on the form of rich multi-media content. This has enabled the inclusion of highly professional asynchronous video lecture recordings as a fundamental element of distance instruction. Furthermore, in many regions of the world, the growth of bandwidth capacity has made it possible to offer synchronous online education.

In a well-executed form, through distance education methods, students and instructors would be able to connect simultaneously, engage in discussions, interact with each other, and collectively advance their learning using synchronous web-based meeting tools. Therefore, it is no surprise that in their seminal work, Christensen and Horn (2016) accurately recognized distance education as a disruptive force in reshaping modern society. As the societal impact of the COVID-19 pandemic demonstrated, there was an urgent need to use distance education to disrupt the harmful effects that the pandemic was forcing upon society (Rippe et al., 2021). What Christensen and Horn argued 
would be an orderly but massive change in the modality of education became an urgent, rapid and explosive event, requiring overnight changes in how educational services are delivered (Sharma, 2021).

It can therefore be argued that the pandemic outbreak may have in fact flipped the disruptive causal relationship, whereby societal forces are disrupting distance education instead of the other way around. The massive societal desire to overcome the constraints of social distancing has created great demands on educators to utilize distance teaching methods. In doing so, society may have challenged the viability and credibility of distance education methods. This is especially true since the rushed deployment of distance education tools, often by faculty with no prior experience in distance teaching, may have compromised student learning. Instead of distance education methods affecting society, it is now society's demands for rapid deployment of distance education methods that can result in student discontent.

\section{Research Questions}

As evident from the above discussion, it is important to understand the nature of the disruptions caused to business education by dissecting the nature of the disruptions that emerged in the months following the pandemic outbreak. To address this, the following research questions need to be empirically addressed:

(1) How did the pandemic outbreak affect business education's unique needs related to team-based learning and group work?

(2) Did the pandemic outbreak influence the ability of business schools to connect their students with the business community?

(3) What effects did the pandemic outbreak have on business students' perceptions of the value of education?

(4) What technological and demographic factors impacted business education in the immediate months following the pandemic outbreak?

In the following section, the above research questions will be empirically addressed. A methodology that utilizes expert reports will be described and the resulting findings will be presented. Following that, a discussion of the implications for business educators and business schools will be discussed.

\section{Methodology}

In order to address the research needs of this study, an exploratory research method utilizing published expert reports was adopted. The objective was to provide a taxonomy of how the pedagogical changes induced in the months following the outbreak of the pandemic, affected business students. It was essential to utilize published expert reports, since descriptive research utilizing large-scale surveys at the time of the pandemic outbreak were not feasible. Use of expert reports as a mode of conducting exploratory research is consistent with prior research studies, which empirically summarize published reports by subject-matter experts, such as journalists, administrators and academicians (Crowe et al., 2011). To identify the expert reports, a bibliographic search engine was utilized. The scope of the studies chosen was filtered to ensure that they relate to business students in the United States in order to match the research objectives of this paper. All the identified expert reports were based on interviews with students or opinions expressed by subject-matter experts (such as university administrators, educational consultants, reporters and professors) reflecting on the impact of the pandemic on business students' learning experiences. This resulted in a total of 16 studies. The identified studies were then examined through a content-analysis procedure (Krippendroff, 2018; Weber, 1985) to categorize the sources of issues affecting the students. Following content analysis procedures, two judges examined the expert reports and formed the thought categories, as the first step. The identified categories

of expressions in the identified studies were then used to produce frequency tabulations which would help reveal the prevalence of specific themes. The full list and citation of the articles are provided in the Appendix. This approach to the analysis of expert reports is consistent with a long stream of prior research in a range of fields, including business, education, and the social sciences (Schreier, 2012).

\section{Findings}

The content analysis of the identified studies indicates challenges in the immediate adjustment period which constitutes the semester in which the outbreak occurred in the United States. The underlying themes related to these challenges have been split into six distinct themes and are outlined below. 


\subsection{Challenges in Learning Through In-person and Team-based Learning Unique to Business Students}

Although students in different fields of study faced obstacles with the transition to online learning as a result of the COVID-19 outbreak, business students experienced unique challenges within their educational ecosystem. This is largely attributed to the pedagogical demands of business education. Business courses are often designed and structured to facilitate hands-on learning experiences for students. As such, many business courses are built to aid students in their person-to-person interactions and to prepare them for their business careers. For example, to facilitate such interactions, students can be assigned team projects and presentations to practice teamwork and asked to engage with guest speakers and industry experts to develop their networking abilities.

The overnight switch to online instruction completely changed this unique feature of business education. The studies examined indicate predominately negative reactions among business students in terms of the pedagogical shift that was forced onto them due to social distancing constraints. The reported student sentiment in the profiled studies suggests that lack of in-person contact disrupted business students' learning and prevented them from attaining the desired one-on-one time with both professors and peers. With the transition to online learning, it became difficult for students to obtain hands-on applicable learning within their groups, which prevented them from experiencing a realistic professional training experience that would replicate business exchanges in a non-socially-distanced world. Similarly, the expert reports indicate that some students viewed the lack of in-person contact as having negatively affected their grades since they had less access to their study groups and may have had difficulty managing online team meetings.

\subsection{Limited Interactions with the Business Community}

The rapid transition to online instruction restricted student access to some of the unique benefits typically offered in business programs such as networking events, pitch competitions, guest speakers, and public speaking workshops. For example, in the post-COVID world, lack of access to in-class guest speakers not only limited students' ability to learn about their major areas of interest in a real-world setting but also hindered the opportunity to craft the necessary professional connections and bonds with industry professionals. The expert reports and studies also indicated a student view that the absence of networking events reduced learning and hindered students' future career opportunities.

In a pre-pandemic world, in-class networking events with industry experts and peers would have helped business students prepare for future professional growth opportunities and form relationships with peers in common fields of interest. In the post-pandemic world, the absence of in-person university-hosted events such as pitch competitions and public speaking workshops significantly reduced such opportunities. For example, pitch competitions are instrumental to aid students in crafting and demonstrating their business skills and gaining feedback from others on their entrepreneurial thinking. Without access to such competitions during the pandemic outbreak semester, business students did not have an outlet to showcase their potential and seek such important feedback. Similarly, the absence of opportunities to practice public speaking in an in-person setting limited students' ability to develop this critical business skill. The expert reports indicated that without access to such essential business education resources, there was great student hesitation about the merits of the new online learning environment as a true substitute for the traditional ways of learning business skills.

\subsection{Justifying the High Cost of Business Education}

Related to the above point, some of the research studies examined for this paper also suggest that the absence of business course resources has put into question the value proposition of business education altogether. This is evident by several studies that have focused on legal challenges to business schools, whereby student coalitions filed lawsuits against universities for failing to deliver the educational content promised. This was especially notable in the case of MBA programs, whereby MBA students from several well-known Ivy League universities demanded tuition refunds on such grounds. The student perspectives that motivated such legal action related to a feeling about the negative effects of online learning environments and concerns that lack of in-person instruction hinders learning and reduces future career opportunities. Faced with crippling student debt, the student sentiment can become amplified, further intensifying the view that online learning is a poor substitute for in-person business education.

\subsection{Technological Gaps}

The adjustment from in-person learning to online learning following the pandemic outbreak was difficult for all students in higher education, including those studying business. Many of the difficulties related to technology access. For example, those students who depended on a university's library for computer work were left to find other means to do so. The task of finding reliable access to the internet was also difficult for some students, as libraries and other 
institutions which provide internet access to students were forced to shut down. This caused a subset of the student body to fall behind their peers in their coursework.

A similar issue often cited by the experts was weak internet connections. Poor Wi-Fi signals can cause students to miss live web-based course lectures put in place as a replacement for face-to-face class meetings. A poor connection can also result in failure to access asynchronous course materials. In some cases, the internet bandwidth issues resulted in falling student grades and strained relationships between professors and students. The issue of data privacy and security was also mentioned in the reviewed studies. For example, some of the video conferencing apps which were implemented as the primary online meeting tool to facilitate synchronous web-based class meetings were breached through hacking attempts. While these security concerns were quickly resolved, they spurred frustration and uncertainty about the feasibility and security of live web-based teaching of business courses in the months following the pandemic outbreak.

\subsection{Challenges in Distance Business Education Unique to International Students}

A review of the expert reports, focusing on the international student experience, indicated a unique set of constraints and challenges in delivering high-quality business education to this segment of the student body using online means. The relevant studies suggested that as a result of the pandemic outbreak, international students experienced significant online learning barriers. Many were forced to return to their home countries as university campuses closed across the United States. Upon their return to home, the difference in time zones caused strife within the international student community, as their course schedules often did not coordinate well with their home time zones. The difference in time made it more likely to miss some of their class meetings and posed coordination challenges to their ability to meet with their professors and peers in the United States. For international students who intended to return, travel restrictions set to block virus transmission also hindered their ability to secure student visas, often due to the closing down of consulates worldwide.

\subsection{Embracing the New Methods of Learning}

Although some business students experienced the negative effects of being forced to adjust to online learning due to the pandemic, the experts' opinions in some of the research articles indicated that a subset of the student body viewed the new model as helpful in their educational experience. For some students, the pandemic created a context for closer relationship with their classmates, who were experiencing similar pressures and constraints in their studies and personal lives. Despite the social distancing forces brought upon by the pandemic, in order to continue the bonds among their students, some professors adapted learning management tools that allow the students to virtually gather together in simulated coffee shops to work on their team projects and assignments. This practice helped their students maintain the pace of teamwork that they had achieved before the pandemic while facilitating closer relationships within their cohorts following the outbreak.

Among the positive aspects of online learning noted by the experts in the studies, there was a recognition for the unique tools available through online modes of teaching. For example, since online learning can be highly conducive to technical content, it allowed students in the analytics fields to master various tools, such as R, Python, Excel and SPSS, using both synchronous and asynchronous content. Also, students in some of the business courses focusing on global business topics were able to take advantage of the pandemic by studying its effects on economies and business models across the world. As such, some faculty were able to quickly revise their courses to cover the effects of the pandemic on the global economy, in real-time.

\section{Implications for the Future of Distance Business Education}

The outbreak of the COVID-19 pandemic rapidly changed the way educational services were delivered to business students worldwide. The results of this study, utilizing expert reports, indicate that these changes manifested themselves in the modality of education and had great impact on student learning and the forms of services expected from a modern business school. This is important, in light of the growing concern overall about the merits and value of business education, especially when considering the high costs (Estelami and Mao, 2019). With respect to the research questions listed, the results indicate that significant impact on team-based learning and group work were evident. The pedagogical demands of business courses, which often rely on teamwork, required the use of distance education tools that would facilitate such modalities of learning.

Given the central role of peer-based learning and teamwork in business education (Choi et al., 2021), the unique educational environment mandated by the pandemic conditions creates a challenge for business students' learning. Related to the second research question, the results of this study indicate significant challenges in helping students 
connect with the business communities, which may be potential employers. The demands of business education, as a means for professional development, require close connections with industry (Fowlie and Forder, 2019). As a result, relating to the third research question of this study, efforts to overcome the demands of social distancing using technology to enable student contact with the business community are essential to protecting the value proposition of business education in a pandemic environment. Finally, with respect to the fourth research question of this study, the results indicate significant technological and demographic gaps experienced by segments of the business student population. Students with limited access to technology tend to suffer in a modality of instruction which is heavily technology-dependent. While segment-based demographic and technological barriers have long been recognized as inhibitors to effective business education (Pittman et al., 2021), the travel restrictions which impacted global mobility uniquely impacted international students following the pandemic, as evident by the research findings.

These forces of change identified through the expert reviews impacted business education in the months immediately following the pandemic. However, many still continue to impact business education and need to be proactively countered and addressed by business schools, in order to best serve all segments of the student population. From an educator's perspective, the pandemic outbreak caused immense pressure to adopt distance teaching tools and methods. As a result, professors with little or no prior online teaching experience found themselves forced to transition to online teaching overnight. Universities with limited distance education resources scrambled for staff and online teaching tools. This scramble had to take place with no advanced contingency planning in place, and in some cases, the absence of budgets needed to undertake the enormous tasks ahead. The net effect has been a generally mixed student sentiment, as evident by the review of the various studies' findings discussed above. There is little doubt that as a result of the pandemic, the perceived quality of what is labeled as "online education" has depleted. This is because many post-pandemic "online" courses were never subjected to the long and methodical processes of online course development, were not scrutinized and perfected using quality control steps used in online education, and as such would not have qualified as being an "online" under normal circumstances. Instead, they were all of a sudden categorized as "online" simply because they were utilizing an online learning management system or were holding class meetings using an online web-meeting platform. Therefore, these courses, which were developed on-the-fly, were all of a sudden put on equal footing with traditional online courses that in the pre-pandemic times, may have taken months or years of methodical planning and course development.

Furthermore, faculty teaching these courses often had little or no formal training on online instruction during the chaotic period following the pandemic outbreak. As such, the blurring of the distinction between the pre- and post-pandemic "online" course is highly problematic for long-term health of business schools. For example, professors who may have had no formal training on how to teach online and may have had no conception of what online teaching is all about prior to the pandemic may now consider themselves as true online educators. As such, it can be argued that online courses developed immediately in response to the pandemic cannot be expected to have equal quality as those developed prior to the pandemic, and there is a need for closer oversight and inspection of these courses in order to ensure quality delivery of course content to business students in years to come.

The pandemic outbreak may have also triggered a restructuring of business education for years to come. For example, it can be expected that those business schools that have adapted better to the demanded changes resulting from the pandemic will be better equipped to experience competitive advantages from these changes in the long-term. Adaptation measures can be in the form of formal training of faculty, monitoring of online course quality, providing faculty with the needed course development resources, and identifying the right platforms and technologies to effectively address the unique needs of business students in the coming years. If history in other industries is to serve as a lesson, it can be easily argued that those business schools that had already begun to transition to online instruction prior to the pandemic, would strategically benefit from the changes forced by the pandemic, as they would be further ahead in the learning curve associated with distance education.

Only time will tell whether the above propositions are true, as the survival and performance of business schools in the post-pandemic environment will only become apparent with the passage of time. Business education may experience restructuring on a faster and more impactful scale than ever seen before. It is possible that due to simple evolutionary market processes and the notion of the survival of the fittest, those schools that do not have a unique selling proposition and have not differentiated themselves sufficiently will fail to survive in the long-term. On the other hand, those schools that can successfully differentiate themselves and are effective in delivering a meaningful value proposition because of factors such as having a prestigious name, specialized programs, or a strategic campus location are more likely to thrive. As such, being 'average' may no longer be a sufficient condition for success.

Since many online program offerings rely on both asynchronous content (for example, video lectures, online 
instructional readings, etc.) and synchronous class meetings, there may also be long-term effects on business schools, resulting from the demands for the production of asynchronous course content. This is because the creation of asynchronous material is one of the greatest challenges in terms of time, content design, and production cost for most institutions. It is possible that the hurdle of asynchronous content development can be reduced or eliminated by the efforts of entities outside the organizational structure of the typical business school. The prime candidates for taking on such an effort would be textbook publishers and educational media companies. Textbook publishers are the producers of the raw material used in higher education. Material such as books and cases are the bread-and-butter of publishers. If instead of simple textbooks, publishers produce consumable asynchronous content, such as video lectures and other forms of multi-media content, then the task of the average professor who has to struggle to produce his/her own asynchronous lecture material would become much more manageable. This would also enable standardization of course content across professors, and arguably across business schools.

At the same time, the potential for the increased role of textbook publishers in producing asynchronous course content could result in the depletion of the value of the typical professor in a business school. This is because the professor would have a diminished role as the primary means of knowledge transmission to the students, as this role would be taken over through the publishers' produced asynchronous multi-media material. In such a case, the professor's role as the educator would be relegated for the most part to the curation of content produced by others, rather than as the creator and lecturer of the content. The net effect of these shifts can be a rapid increase in the contribution and value of textbook publishers and a significant reduction in the role and importance of universities and their professors as content creators and disseminators.

\section{Conclusion}

The coronavirus pandemic has significantly impacted higher education globally. The quick transition to online education in the months following the outbreak created many challenges for college students across the world. Business students have uniquely felt the effects of the changes brought about by the pandemic. As indicated by the review of the expert reports profiled in this paper, the removal of a hands-on learning approach within business courses and the limited access to business student resources such as networking events, public speaking workshops, pitch competitions, and professional development training have negatively affected business students' learning experiences.

The challenges to instructional quality due to the massive flight of business schools to online teaching will eventually demand a purification process, through which quality control procedures would need to be implemented to ensure that meaningful student learning is achieved. Faculty who have had to scramble to learn and adopt distance teaching methods will need to continue their own learning and perfection of these methods. From a strategic perspective, those business schools that value and respond to the mandate for quality online teaching will likely become more prominent in the coming years, as they will develop unique selling propositions and points of differentiation that are valued by the business student of the future. It is hoped that this paper has triggered additional research and discussion on the post-pandemic strategies needed for successful delivery of online business education.

\section{References}

Allen, I. E., \& Seaman, J. (2013). Changing course: ten years of tracking online education in the United States. Boston: Babson Survey Research Group.

Carey, K. (2020). Everybody ready for the big migration to online college? Actually, no. The New York Times (March 13, 2020). Retrieved from https://www.nytimes.com/2020/03/13/upshot/coronavirus-online-college-classes-unprepared.html

Choi, S., Slaubaugh, M., \& Tian, Z. (2021). Integrating learning interpersonal skills through team-based learning (TBL) in a management course. Journal of Education for Business, 96(8), 498-509. https://doi.org/10.1080/08832323.2020.1868962

Christensen, C. M., \& Horn, M. B. (2016). Disrupting class: how disruptive innovation will change the way the world learns. New York: McGraw-Hill.

Crowe, S., Cresswell, K., Robertson, A., Huby, G., Avery, A., \& Sheikh, A. (2011). The case study approach. BMC Med Res Methodol, 11(100). https://doi.org/10.1186/1471-2288-11-100

Dincher, M., \& Wagner, V. (2021). Teaching in times of COVID-19: determinants of teachers' educational 
technology use. Education Economics, 29(5), 461-470. https://doi.org/10.1080/09645292.2021.1920000

Edelson, P. J., \& Pittman, V. V. (2008). Historical perspectives on distance learning. In W.J. Bramble and S. Panda (Eds.), Economics of Distance and Online Learning: Theory, Practice and Research. New York: Routledge. https://doi.org/10.4324/9780203892985.ch5

Estelami, H., \& Mao, Z. (2019). An empirical study of the determinants of tuition for online MBA programs. American Journal of Business Education, 12(1), 1-9. https://doi.org/10.19030/ajbe.v12i1.10252

Fowlie, J., \& Forder, C. (2019). Future-proofing placements: The importance of local opportunities for placement students. Higher Education, Skills and Work-Based Learning, 9(3), 434-444. https://doi.org/10.1108/HESWBL-07-2018-0076

Krippendroff, K. (2018). Content analysis: an introduction to its methodology. London: Sage Publications.

Pittman, J., Severino, L., DeCarlo-Tecce, M. J., \& Kiosoglous, C. (2021). An action research case study: digital equity and educational inclusion during an emergent COVID-19 divide. Journal for Multicultural Education, 14(1), 68-84. https://doi.org/10.1108/JME-09-2020-0099

Priluck, R. (2004). Web-assisted courses for business education: an examination of two sections of principles of marketing. Journal of Marketing Education, 26(2), 161-173. https://doi.org/10.1177/0273475304265635

Rippe, C., Suri, W. S., Yurova, Y., \& Kemp, A. (2021). Pandemic pedagogy for the new normal: fostering perceived control during COVID-19. Journal of Marketing Education, 43(2), 260-276. https://doi.org/10.1177/0273475320987287

Schreier, M. (2012). Qualitative content analysis in practice. London: Sage Publications.

Schwab, K., \& Malleret, T. (2020). COVID-19: The great reset. Centerport, NY: Forum Publishing.

Sharma, S. (2021). The challenges faced in technology-driven classes during COVID-19. International Journal of Distance Education Technologies, 19(1), 66-71. https://doi.org/10.4018/IJDET.20210101.oa2

Simonson, M., Smaldino, S., Albright M., \& Zvacek, S. (2009). Teaching and learning at a distance: Foundations of Distance Education. Boston: Pearson Education.

Valeeva, M. (2021). Economic development and environmental economics impact because of COVID-19. Journal of Economics and Economic Education Research, 22(4), 1-2.

Weber, R. P. (1985). Basic content analysis. London: Sage Publications.

Welna, D. (2020). Coronavirus Has Now Killed More Americans Than Vietnam War. NPR. Retrieved April 28, 2020 from https://www.npr.org/sections/coronavirus-live-updates/2020/04/28/846701304/pandemic-death-toll-in-u-s-nowexceeds-vietnam-wars-u-s-fatalities

Whatley, J. (2012). Evaluation of team project-based learning module for developing employability skills. Issues in Informing Science and Information Technology, 9, 75-92. https://doi.org/10.28945/1605 


\section{Appendix}

Table 1. List of the Studies Used in the Content Analysis

\begin{tabular}{|c|c|c|c|}
\hline Authors & Study Title & Publication & Study Link \\
\hline Kowarski (2020) & $\begin{array}{l}\text { "What Covid-19 Means for } \\
\text { International MBA Students" }\end{array}$ & $\begin{array}{l}\text { U.S. News \& } \\
\text { World Report }\end{array}$ & $\begin{array}{l}\text { https:/www.usnews.com/education/best-graduate-schools/top } \\
\text {-business-schools/articles/how-coronavirus-affects-admitted- } \\
\text { prospective-international-mba-students }\end{array}$ \\
\hline Byrne (2020) & $\begin{array}{l}\text { "The New Covid-19 MBA } \\
\text { Admissions Round" }\end{array}$ & Poets \& Quants & $\begin{array}{l}\text { https://poetsandquants.com/2020/03/27/the-new-covid-19-mb } \\
\text { a-admissions-round/ }\end{array}$ \\
\hline Ziady (2020) & $\begin{array}{l}\text { "She Paid } \$ 68,000 \text { to do an MBA at } \\
\text { Cambridge. Now She's Studying via } \\
\text { Zoom in India" }\end{array}$ & $\mathrm{CNN}$ & $\begin{array}{l}\text { https://www.cnn.com/2020/04/22/business/business-schools- } \\
\text { coronavirus/ }\end{array}$ \\
\hline Byrne (2020) & $\begin{array}{l}\text { "Harvard MBA Students Join } \\
\text { Growing Calls for Tuition Refunds" }\end{array}$ & Poets \& Quants & $\begin{array}{l}\text { https://poetsandquants.com/2020/04/13/harvard-mba-students } \\
\text {-join-growing-calls-for-tuition-refunds/ }\end{array}$ \\
\hline Symonds (2020) & $\begin{array}{l}\text { "What Online MBA Candidates } \\
\text { Need To Know About The Online } \\
\text { GMAT" }\end{array}$ & Forbes & $\begin{array}{l}\text { https://www.forbes.com/sites/mattsymonds/2020/04/24/what- } \\
\text { mba-candidates-need-to-know-about-the-online-gmat/\#f5ble } \\
6137 \text { c53 }\end{array}$ \\
\hline Nugent (2020) & $\begin{array}{l}\text { "How Coronavirus Is Affecting } \\
\text { MBA Students" }\end{array}$ & Business Because & $\begin{array}{l}\text { https://www.businessbecause.com/news/coronavirus-latest/67 } \\
\text { 91/coronavirus-affecting-mba-students }\end{array}$ \\
\hline $\begin{array}{l}\text { Wharton MBA } \\
\text { Students (2020) }\end{array}$ & $\begin{array}{l}\text { "Wharton MBA's Petition for Lower } \\
\text { Tuition Fees" }\end{array}$ & Business Because & $\begin{array}{l}\text { https://www.businessbecause.com/news/coronavirus-latest/68 } \\
\text { 69/wharton-mba-petition-lower-tuition-fees }\end{array}$ \\
\hline Lovick (2020) & $\begin{array}{l}\text { "How Online Learning Is Preparing } \\
\text { MBAs For Remote Work" }\end{array}$ & Business Because & $\begin{array}{l}\text { https://www.businessbecause.com/news/mba-degree/6888/ho } \\
\text { w-online-learning-remote-work }\end{array}$ \\
\hline $\begin{array}{l}\text { "Business Because" } \\
(2020)\end{array}$ & $\begin{array}{l}\text { "What Is the Impact of Coronavirus } \\
\text { on Business Schools?" }\end{array}$ & Business Because & https://www.businessbecause.com/news/live/coronavirus \\
\hline Dhariyal (2020) & $\begin{array}{l}\text { "MBA Admission: Covid-19 Impact } \\
\text { on Applicants \& Students" }\end{array}$ & E-Gmat & https://e-gmat.com/blogs/ \\
\hline Freire (2020) & $\begin{array}{l}\text { "Shaping the Future of Business } \\
\text { Education in a Post-Covid World" }\end{array}$ & Juan Freire & $\begin{array}{l}\text { https://juanfreire.com/shaping-the-future-of-business-educati } \\
\text { on-in-a-post-covid-world/ }\end{array}$ \\
\hline Iacurci (2020) & $\begin{array}{l}\text { "Wharton Business School is Using } \\
\text { the Coronavirus Pandemic as a } \\
\text { Learning Opportunity" }\end{array}$ & $\mathrm{CNBC}$ & $\begin{array}{l}\text { https://www.cnbc.com/2020/03/12/coronavirus-wharton-busi } \\
\text { ness-school-offers-new-course-about-pandemic.html }\end{array}$ \\
\hline Goldberg (2020) & $\begin{array}{l}\text { "4 Tips for Adapting an Experiential } \\
\text { Learning Course from Real World to } \\
\text { Online - during (and after) the } \\
\text { Coronavirus" }\end{array}$ & Forbes & $\begin{array}{l}\text { https://www.forbes.com/sites/michaelegoldberg/2020/03/13/4 } \\
\text {-tips-for-adapting-an-experiential-learning-course-from-real- } \\
\text { world-to-online-during-and-after-the-coronavirus/\#7c5f9cba6 } \\
\text { 3dd }\end{array}$ \\
\hline $\begin{array}{l}\text { "Stanford School of } \\
\text { Business MBA } \\
\text { Students Class of } \\
2020 \text { and } 2021 \text { " } \\
(2020)\end{array}$ & $\begin{array}{l}\text { "Tuition Discount for Spring Quarter } \\
\text { at Stanford Graduate School of } \\
\text { Business" }\end{array}$ & Change.org & $\begin{array}{l}\text { https://www.change.org/p/stanford-graduate-school-of-busine } \\
\text { ss-tuition-discount-for-spring-quarter-at-stanford-graduate-sc } \\
\text { hool-of-business?recruiter=1012391795\&recruited_by_id=78 } \\
\text { 22d610-f764-11e9-83a9-e1dd470462d3\&utm_source=share_- } \\
\text { petition\&utm_medium=copylink\&utm_campaign=petition_d } \\
\text { ashboard }\end{array}$ \\
\hline $\begin{array}{l}\text { "The HBS MBA } \\
\text { Classes of } 2020 \text { and } \\
2021 "(2020)\end{array}$ & $\begin{array}{l}\text { "Partial Tuition Refund for Spring } \\
\text { Term at Harvard Business School" }\end{array}$ & Change.org & $\begin{array}{l}\text { https://www.change.org/p/dean-nitin-nohria-an-academic-rei } \\
\text { mbursement-of- } 80 \text {-for-the-portion-of-classes-that-were-onlin } \\
\text { e }\end{array}$ \\
\hline $\begin{array}{l}\text { "The Wharton School } \\
\text { MBA Class of } 2020 \\
\text { and } 2021 "(2020)\end{array}$ & $\begin{array}{l}\text { "Wharton MBA Community: } \\
\text { Petition for Dialogue on Tuition } \\
\text { Relief and/or Other Assistance" }\end{array}$ & Change.org & $\begin{array}{l}\text { https://www.change.org/p/wharton-mba-community-petition- } \\
\text { for-dialogue-on-tuition-relief-and-or-other-assistance }\end{array}$ \\
\hline $\begin{array}{l}\text { "Columbia Business } \\
\text { School MBA Class of } \\
2020 \text { and } 2021 " \\
(2020)\end{array}$ & $\begin{array}{l}\text { "Petition for Tuition Refunds at } \\
\text { Columbia Business School" }\end{array}$ & Change.org & $\begin{array}{l}\text { https://www.change.org/p/petition-for-tuition-refunds-at-colu } \\
\text { mbia-business-school?source_location=topic_page }\end{array}$ \\
\hline
\end{tabular}




\section{Copyrights}

Copyright for this article is retained by the author(s), with first publication rights granted to the journal.

This is an open-access article distributed under the terms and conditions of the Creative Commons Attribution license (http://creativecommons.org/licenses/by/4.0/). 